\title{
Changes of Platelet Indices in Patients with Systemic Lupus Eythematosus and their Correlation with Disease Activity
}

\author{
WAFAA M. SHERIF, M.Sc. ${ }^{1}$; RASHA A. ABDEL NOOR, M.D. ${ }^{2}$; MOHAMED ATTIA, M.D. ${ }^{3}$ and \\ NASHWA NOR EL-DEEN, M.D. ${ }^{4}$ \\ The Departments of Internal Medicine ${ }^{1}$, Internal Medicine \& Rheumatology ${ }^{2}$, Clinical Pathology ${ }^{3}$ and Internal Medicine \& \\ Hematology ${ }^{4}$, Faculty of Medicine, Tanta University, Tanta, Egypt
}

\begin{abstract}
Background: Systemic lupus erythematosus (SLE) is autoimmune disease needs continuous assessment of disease activity. There is no single biomarker used for that purpose. Platelet indices have recently been found to be a simple inflammatory marker used in the assessment of systemic inflammation in many diseases like, rheumatoid arthritis, ankylosing spondylitis and inflammatory bowel diseases.
\end{abstract}

Aim of Study: To evaluate platelet indices [mean platelet volume (MPV), platelet distribution width (PDW) and plateletcrit (PCT)] as markers of disease activity in patients with SLE.

Patients and Methods: In this cross sectional study we tested 100 subjects; 20 healthy control and 80 SLE patients recruited from rheumatology unit in Internal Medicine Department, Tanta University, Tanta, Egypt. Then the lupus patients were divided according to SLEDAI into 20 patients without flare (SELEDAI $<4), 17$ patients mild flare (SELEDAI $4-<8$ ), 25 patients moderate flare (SELEDAI $8-<12$ ) and 18 patients severe flare (SELEDAI > 12). Platelet indices (MPV, PDW, PTC) were assessed in all of them and their correlation to SLEDAI score were analyzed.

Results: MPV and PDW had no clinical significance in assessing lupus activity, PCT significantly lower with SLE patients with severe flare and it had a significant negative correlation with SELEDAI score with cutoff value equals $<0.173$, sensitivity $61.11 \%$, specificity $79.03 \%$, PPV $45.8 \%$ and NPV $87.5 \%$. Finally there was no significant difference between lupus nephritis and lupus without nephritis patients in Platelet indices.

Conclusion: Plateletcrit (PCT) can be used as a new marker for SLE activity.

Key Words: SLE - Lupus activity -SLEDAI - Platelet indices - Mean platelet volume - Platelet-crit-Platelet distribution width.

Correspondence to: Dr. Rasha A. Abdel Noor,

E-Mail: rashaabdelnoor@yahoo.com rashaabdelnoor@med.tanta.edu.eg

\section{Introduction}

SYSTEMIC lupus erythematosus (SLE) is a multisystem autoimmune disease. Considering its remitting and relapsing nature, it is important to have a biomarker to monitor its disease activity $[1,2]$ There is no single biomarker for that purpose till now but there are many validated measures, including Systemic Lupus Erythematosus Disease Activity Index (SLEDAI-SLENA), European Consensus Lupus Activity Measurement (ECLAM), British Isles Lupus Activity Group(BILAG) ... etc [3-6] These tools have been found to be beneficial in day to day practice. Most of these activity indices use multiple parameters like clinical and laboratory parameters some of them are simple, easy to use in routine clinical practice like urine analysis, platelet and leucocyte counts, others may not be simply assessed during routine follow-up of patients like Anti-dsDNA titer, C3, C4. Platelet indices [Mean platelet volume (MPV) and platelet distribution width (PDW) and platelet-crit (PCT)] are a group of platelet parameters determined in automatic CBC profiles; they are related to platelets' morphology and proliferation kinetics and represent platelet activation. Mean platelet volume (MPV) is the mode of the measured platelet volume. Typically, the average mean cell volume is 7.2-11.7 $\mathrm{fL}$ in healthy subjects is an indicator of platelet function. It reflects activation of the platelets and it has been found to be related with inflammatory conditions, Under normal circumstances when platelet production is decreased, young platelets become bigger and more active so there is an inverse relationship between platelet size and number $[\mathbf{7 , 8}]$. Platelet indices has been studied as an inflammatory marker in several diseases. Some studies have reported that MPV increases in myocardial infarction and cerebrovascular disease; 
while in contrast, it decreases in active rheumatologic diseases including rheumatoid arthritis, ankylosing spondylitis and ulcerative colitis $[\mathbf{9 , 1 2}]$ Platelet distribution width ( PDW) is an indicator of volume variability in platelets size and is increased in the presence of platelet anisocytosis [13]. Platelet-crit (PCT) is the volume occupied by platelets in the blood as a percentage and calculated according to the formula $\mathrm{PCT}=$ Platelet count $\mathrm{x}$ MPV/10,000 The normal range for PCT is 0.22$0.24 \%$. In healthy subjects, platelet mass is closely regulated to keep it constant [14].

The present study aimed to investigate changes of mean platelet volume, platelet distribution width and platelet-crit in patient with SLE and their correlation with disease activity.

\section{Patients and Methods}

This cross sectional study was conducted on 100 subjects; 80 SLE patients were recruited from rheumatology unit of Internal Medicine Department (inpatient wards and outpatient clinics) of Tanta University Hospitals and 20 age and sex matched healthy persons as a control group in the period between May 2017 to April 2018.

\section{Inclusion criteria:}

Patients with 4 or more criteria of the 2012 SLICC criteria (the Systemic Lupus International Collaborating Clinic) [15] and disease activity was assessed by the SLE Disease Activity Index (SLEDAI) [16]

\section{Exclusion criteria:}

Other autoimmune diseases, malignancies and Infections:

This study is in agreement with the ethical guidelines of the Declaration of Helsinki and it follows the ethical standards of Tanta Faculty of Medicine. Informed consents from all patients were obtained in accordance with the local ethical committee. Privacy of all patients' data was granted as there was a code number for every patient file that includes all investigations.

\section{All controles (group 1) and the patients (group} 2) were subjected to:

Thorough history taking,Complete clinical examination, searching for signs of lupus activity.

\section{Laboratory investigations including:}

Complete blood count including (Mean platletvolume, platelet distribution width and platelet- crit) were determined by using BCC-3000 Auto Hematology Analyzer within two hours of collection. Blood Urea and serum creatinine, Liver function tests, Erythrocyte Sedimentation Rate (ESR), C-reactive protein (CRP), Urine analysis, 24 hour urine proteins. Anti-Nuclear Antibody (ANA), Anti-ds DNA titer was done by ELISA.

Reference value: Negative: $<40 \mathrm{U} / \mathrm{ml}$. Equivocal: 40-60 U/ml. Positive: $>60 \mathrm{U} / \mathrm{ml}$.

Serum complement levels (C3 \& C4) and Renal biopsy with histo-pathological examination, grading and determination of activity and chronicity indices of Lupus Nephritis.

Disease activity was assessed using the SLE disease activity index (SLEDAI) score and the SLE patients were divided into 4 subgroups:

$$
\begin{aligned}
& \text { a- Without flare (were SELEDAI <4). } \\
& \text { b- Mild flare }(4-<8) \text {. } \\
& \text { c- Moderate flare }(8-<12) \text {. } \\
& \text { d- Severe flare }(>\text { or }=12) \text {. }
\end{aligned}
$$

\section{Statistical analysis:}

Data were fed to the computer and analyzed using IBM SPSS software package version 20.0. Qualitative data were described using number and percent. The Kolmogorov-Smirnov test was used to verify the normality of distribution Quantitative data were described using range (minimum and maximum), mean, standard deviation and median. Significance of the obtained results was judged at the $5 \%$ level.

\section{Results}

Our SLE patients are divided according to SLEDAI score into 4 groups and the demographic data, diseases duration are shown in Tables $(1,2)$.

Regarding the CBC parameters and plateletindices, there was significant difference in $\mathrm{Hb} \%$, Hematocrit value, platelet count and platelet-crit between control and patient groups with marked decrease in platelet-crit in SLE patients with severe lupus flare and this is shown in Tables $(3,4)$.

Table (1): Distribution of the studied cases according to SELEDAI score.

\begin{tabular}{lcc}
\hline SELEDAI score & No. & $\%$ \\
\hline Without flare $(<4)$ & 20 & 25.0 \\
Mild flare (4-<8) & 17 & 21.3 \\
Moderate flare (8-12) & 25 & 31.3 \\
Severe flare $(>12)$ & 18 & 22.5 \\
Min. - Max. & & $0.0-28.0$ \\
Median & & 8.0 \\
\hline
\end{tabular}


Table (2): Comparison between the different studied groups according to demographic data.

\begin{tabular}{|c|c|c|c|c|c|c|c|c|c|c|c|c|}
\hline & \multicolumn{10}{|c|}{ SLE patients $(\mathrm{n}=80)$} & \multirow{3}{*}{$\begin{array}{l}\text { Test } \\
\text { of Sig. }\end{array}$} & \multirow{3}{*}{$p$} \\
\hline & \multicolumn{2}{|c|}{$\begin{array}{l}\text { Control } \\
(\mathrm{n}=20)\end{array}$} & \multicolumn{2}{|c|}{$\begin{array}{c}\text { Without } \\
\text { flare }(<4) \\
(\mathrm{n}=20)\end{array}$} & \multicolumn{2}{|c|}{$\begin{array}{c}\text { Mild flare } \\
(4-<8) \\
(\mathrm{n}=17)\end{array}$} & \multicolumn{2}{|c|}{$\begin{array}{c}\text { Moderate } \\
\text { flare }(8-12) \\
(\mathrm{n}=25)\end{array}$} & \multicolumn{2}{|c|}{$\begin{array}{c}\text { Severe } \\
\text { flare }(>12) \\
(\mathrm{n}=18)\end{array}$} & & \\
\hline & No. & $0 / 0$ & No. & $\%$ & No. & $\%$ & No. & $0 / 0$ & No. & $\%$ & & \\
\hline $\begin{array}{l}\text { Sex: } \\
\quad \text { Male } \\
\text { Female }\end{array}$ & $\begin{array}{l}6 \\
14\end{array}$ & $\begin{array}{l}30.0 \\
70.0\end{array}$ & $\begin{array}{l}3 \\
17\end{array}$ & $\begin{array}{l}15.0 \\
85.0\end{array}$ & $\begin{array}{l}1 \\
16\end{array}$ & $\begin{array}{l}5.9 \\
94.1\end{array}$ & $\begin{array}{l}1 \\
24\end{array}$ & $\begin{array}{l}4.0 \\
96.0\end{array}$ & $\begin{array}{l}0 \\
18\end{array}$ & $\begin{array}{l}0.0 \\
100.0\end{array}$ & $\begin{array}{l}\chi^{2}= \\
9.471 *\end{array}$ & $\begin{array}{l}\mathrm{MC}_{p}= \\
0.021 *\end{array}$ \\
\hline $\begin{array}{l}\text { Age (years): } \\
\text { Min. - Max. } \\
\text { Mean } \pm \text { SD. }\end{array}$ & \multicolumn{2}{|c|}{$\begin{array}{c}19.0-45.0 \\
8.03 \pm 31.75\end{array}$} & \multicolumn{2}{|c|}{$\begin{array}{c}15.0-51.0 \\
10.85 \pm 30.20\end{array}$} & \multicolumn{2}{|c|}{$\begin{array}{r}19.0-50.0 \\
8.97 \pm 30.41\end{array}$} & \multicolumn{2}{|c|}{$\begin{array}{c}14.0-54.0 \\
9.78 . \pm 27.32\end{array}$} & \multicolumn{2}{|c|}{$\begin{array}{c}18.0-55.0 \\
8.61 \pm 32.22\end{array}$} & $\begin{array}{l}\mathrm{F}= \\
0.943\end{array}$ & 0.443 \\
\hline $\begin{array}{l}\text { Duration } \\
\text { (month) }\end{array}$ & \multicolumn{2}{|c|}{$\begin{array}{l}\text { Without flare } \\
(<4)(\mathrm{n}=20)\end{array}$} & \multicolumn{3}{|c|}{$\begin{array}{l}\text { Mild flare } \\
\quad(4-<8) \\
(\mathrm{n}=17)\end{array}$} & \multicolumn{3}{|c|}{$\begin{array}{l}\text { Moderate flare } \\
(8-12)(\mathrm{n}=25)\end{array}$} & \multicolumn{2}{|c|}{$\begin{array}{l}\text { Severe flare } \\
(>12)(\mathrm{n}=18)\end{array}$} & $\mathrm{H}$ & $p$ \\
\hline $\begin{array}{l}\text { Min. - Max. } \\
\text { Median }\end{array}$ & \multicolumn{2}{|c|}{$\begin{array}{l}12.0-288.0 \\
60.0\end{array}$} & \multicolumn{3}{|c|}{$0.25-288.0$} & $\begin{array}{l}0.2 \\
24\end{array}$ & 80.0 & & $\begin{array}{l}0.25-132 \\
30.0\end{array}$ & & $8.333^{*}$ & $0.040^{*}$ \\
\hline Sig. bet. grps. & \multicolumn{10}{|c|}{$p_{1}=0.023^{*}, p_{2}=0.011^{*}, p 3=0.028^{*}, p_{4}=0.972, p_{5}=0.915, p_{6}=0.879$} & & \\
\hline
\end{tabular}

$\chi^{2}$ : Chi square test. MC: Monte Carlo. $\quad$ F: ANOVA test. $\quad$ p: $p$-value for comparing between the different groups.

* : : Statistically significant at $p \leq 0.05$

$\mathrm{H}$ : Kruskal Wallis test, Pairwise comparison bet. each 2 groups was done using Post Hoc Test (Dunn's for multiple comparisons test). $p: p$-value for comparing between the different groups. $p_{1}: p$-value for comparing between control group and each other groups;. $p_{2}: p$-value for comparing between without flare and mild flare. $\quad \mathrm{p} 3: \mathrm{p}$-value for comparing between without flare and moderate flare. $p_{4}: p$-value for comparing between without flare and severe flare. $\quad \mathrm{p} 5: \mathrm{p}$-value for comparing between mild flare and moderate flare. $p_{6}: p$-value for comparing between mild flare and severe flare. $\quad \mathrm{p} 7: \mathrm{p}$-value for comparing between moderate flare and severe flare.

* : : Statistically significant at $p \leqq 0.05$.

Table (3): Comparison between the different studied groups according to CBC.

\begin{tabular}{|c|c|c|c|c|c|c|c|}
\hline \multirow[b]{2}{*}{$\mathrm{CBC}$} & \multirow[b]{2}{*}{$\begin{array}{l}\text { Control } \\
(n=20)\end{array}$} & \multicolumn{4}{|c|}{ SLE patients $(\mathrm{n}=80)$} & \multirow[b]{2}{*}{$\begin{array}{l}\text { Test } \\
\text { of Sig. }\end{array}$} & \multirow[b]{2}{*}{$p$} \\
\hline & & $\begin{array}{c}\text { Without } \\
\text { flare }(<4) \\
(\mathrm{n}=20)\end{array}$ & $\begin{array}{l}\text { Mild flare } \\
(4-<8) \\
(\mathrm{n}=17)\end{array}$ & $\begin{array}{c}\text { Moderate } \\
\text { flare }(8-12) \\
(\mathrm{n}=25)\end{array}$ & $\begin{array}{c}\text { Severe } \\
\text { flare }(>12) \\
(\mathrm{n}=18)\end{array}$ & & \\
\hline \multicolumn{8}{|l|}{$H g b(g / d l):$} \\
\hline Min.-Max. & $10.20-14.50$ & $5.30-14.0$ & $8.30-14.40$ & $6.20-15.0$ & $7.10-14.0$ & $\mathrm{~F}=2.984 *$ & $0.023 *$ \\
\hline Mean \pm SD. & $11.97 \pm 1.34$ & $10.68 \pm 2.52$ & $11.17 \pm 1.50$ & $10.02 \pm 2.08$ & $10.56 \pm 2.06$ & & \\
\hline pl & & 0.239 & 0.732 & $0.011 *$ & 0.186 & & \\
\hline Sig. bet. grps & \multicolumn{7}{|c|}{$p_{2}=0.942, p_{3}=0.796, p_{4}=1.000, p_{5}=0.345, p_{6}=0.890, p_{7}=0.900$} \\
\hline \multicolumn{8}{|l|}{$\operatorname{MCV}(f l)$} \\
\hline Min. - Max. & $76.0-87.80$ & $62.0-94.0$ & $70.20-97.0$ & $71.0-95.0$ & $79.0-97.0$ & 2.00 & 0.101 \\
\hline Mean \pm SD & $82.52 \pm 3.46$ & $81.47 \pm 7.45$ & $82.31 \pm 6.59$ & $80.17 \pm 6.11$ & $85.14 \pm 4.52$ & & \\
\hline \multicolumn{8}{|l|}{ HCT (\%) } \\
\hline Min. - Max. & $31.0-42.0$ & $17.90-42.0$ & $24.0-42.0$ & $16.50-46.70$ & $21.90-45.80$ & $\mathrm{~F}=2.556^{*}$ & $0.044 *$ \\
\hline Mean \pm SD. & $36.11 \pm 3.76$ & $32.71 \pm 7.13$ & $33.81 \pm 4.47$ & $30.61 \pm 6.65$ & $32.33 \pm 6.37$ & & \\
\hline p1 & & 0.370 & 0.762 & $0.021 *$ & 0.290 & & \\
\hline Sig. bet. grps & \multicolumn{7}{|c|}{$p_{2}=0.980, p_{3}=0.796, p_{4}=0.758, p_{5}=1.000, p_{6}=0.426, p_{7}=0.879$} \\
\hline \multicolumn{8}{|l|}{$\operatorname{PLT}\left(x 10^{3} / u l\right):$} \\
\hline Min. - Max. & $197.0-313.0$ & $97.0-431.0$ & $89.0-780.0$ & $46.0-663.0$ & $50.0-484.0$ & $\mathrm{H}=$ & $0.022 *$ \\
\hline Median & 269.5 & 258.5 & 277.0 & 229.0 & 169.0 & $11.411^{*}$ & \\
\hline p1 & & 0.401 & 0.994 & 0.327 & $0.003 *$ & & \\
\hline Sig. bet. grps & \multicolumn{7}{|c|}{$p_{2}=0.425, p_{3}=0.924, p_{4}=0.030, p_{5}=0.354, p_{6}=0.004, p_{7}=0.029^{*}$} \\
\hline WBCs $\left(x 10^{3} / u l\right):$ & & & & & & & \\
\hline Min. - Max. & $4.40-10.0$ & $3.0-26.0$ & $3.30-15.0$ & $2.50-15.0$ & $3.80-13.90$ & $\mathrm{H}=$ & 0.911 \\
\hline Mean \pm SD. & $6.81 \pm 1.78$ & $7.84 \pm 5.0$ & $7.08 \pm 3.25$ & $7.69 \pm 2.95$ & $7.57 \pm 3.27$ & 0.995 & \\
\hline
\end{tabular}

F: ANOVA test, Pairwise comparison bet. each 2 groups was done using Post HocTest (Tukey).

$\mathrm{H}$ : Kruskal Wallis test, Pairwise comparison bet. each 2 groups was done using Post Hoc Test (Dunn's for multiple comparisons test).

$p: p$-value for comparing between the different groups. $p_{1}: p$-value for comparing between control group and each other groups. $p 2: p$-value for comparing between without flare and mild flare. $\quad p 3: p$-value for comparing between without flare and moderate flare. $p$ 4: $p$-value for comparing between without flare and severe flare. $\quad$ 5: $p$-value for comparing between mild flare and moderate flare. p 6: $p$-value for comparing between mild flare and severe flare. $\quad p 7: p$-value for comparing between moderate flare and severe flare.

* : Statistically significant at $p \leq 0.05$ 
Table (4): Comparison between the different studied groups according to platelet-indices.

\begin{tabular}{|c|c|c|c|c|c|c|c|}
\hline & \multirow[b]{2}{*}{$\begin{array}{l}\text { Control } \\
(n=20)\end{array}$} & \multicolumn{4}{|c|}{ SLE patients $(\mathrm{n}=80)$} & \multirow[b]{2}{*}{$\begin{array}{c}\text { Test } \\
\text { of Sig. }\end{array}$} & \multirow[b]{2}{*}{$p$} \\
\hline & & $\begin{array}{l}\text { Without } \\
\text { flare }(<4) \\
(n=20)\end{array}$ & $\begin{array}{l}\text { Mild flare } \\
(4-<8) \\
(n=17)\end{array}$ & $\begin{array}{c}\text { Moderate } \\
\text { flare }(8-12) \\
(\mathrm{n}=25)\end{array}$ & $\begin{array}{c}\text { Severe } \\
\text { flare }(>12) \\
(n=18)\end{array}$ & & \\
\hline \multicolumn{8}{|l|}{$M P V(f l):$} \\
\hline Min. - Max. & $9.10-10.50$ & $8.80-10.90$ & $8.0-10.80$ & $8.90-13.60$ & $7.80-13.90$ & \multirow[t]{2}{*}{$F=1.369$} & \multirow[t]{2}{*}{0.251} \\
\hline Mean \pm SD & $9.94 \pm 0.30$ & $9.84 \pm 0.64$ & $9.67 \pm 0.72$ & $10.07 \pm 1.02$ & $10.41 \pm 1.76$ & & \\
\hline \multicolumn{8}{|l|}{$P D W(\%):$} \\
\hline Min. - Max. & $10.70-18.80$ & $5.80-18.0$ & $9.40-18.80$ & $9.10-19.70$ & $8.90-19.40$ & \multirow{2}{*}{$\begin{array}{l}\mathrm{F}= \\
1.088\end{array}$} & \multirow[t]{2}{*}{0.367} \\
\hline Mean \pm SD & $14.27 \pm 2.17$ & $12.94 \pm 3.0$ & $13.35 \pm 2.27$ & $13.81 \pm 2.98$ & $12.68 \pm 3.06$ & & \\
\hline \multicolumn{8}{|l|}{$\operatorname{PCT}(\%):$} \\
\hline Min. - Max. & $0.027-0.307$ & $0.102-0.383$ & $0.095-0.632$ & $0.062-0.616$ & $0.050-0.440$ & \multirow{3}{*}{$\begin{array}{l}\mathrm{H}= \\
14.073\end{array}$} & \multirow[t]{3}{*}{$0.007 *$} \\
\hline Median & 0.257 & 0.255 & 0.271 & 0.224 & 0.159 & & \\
\hline $\mathrm{p} 1$ & & 0.394 & 0.898 & 0.264 & $0.001^{*}$ & & \\
\hline Sig. bet. grps & \multicolumn{7}{|c|}{$p_{2}=0.490, p_{3}=0.828, p_{4}=0.011, p_{5}=0.351, p_{6}=0.002, p_{7}=0.014^{*}$} \\
\hline
\end{tabular}

F: ANOVA test. H:Kruskal Wallis test, Pairwise comparison bet. each 2 groups was done using Post Hoc Test (Dunn's for multiple comparisons test). $p: p$-value for comparing between the different groups. $\quad p_{1}: p$-value for comparing between control group and each other groups. $p 2: p$-value for comparing between without flare and mild flare. $\quad p 3: p$-value for comparing between without flare and moderate flare. $p 4: p$-value for comparing between without flare and severe flare. $\quad p_{5}: p$-value for comparing between mild flare and moderate flare. p6: $p$-value for comparing between mild flare and severe flare. $\quad p 7: p$-value for comparing between moderate flare and severe flare. * : Statistically significant at $p \leq 0.05$.

Our results showed also no significant differences as regard platelet indices between lupus nephritis and lupus without nephritis patients (Table 5).

There was also significant negative correlation between platelet crit (PCT) \% and SLEDAI score
(Table 6, Fig. 1) and the receiver operating characteristic curve (ROC) curve showed that plateletcrit has a cutoff value equal $\leq 0.173,61.11 \%$ sensitivity $79.03 \%$ specificity, $45.8 \%$ PPV and $87.5 \%$ NPV in differentiating lupus patients with severe flare from other lupus patients (Table 7, Fig. 2).

Table (5): Comparison between the control group, and lupus nephritis patients and lupus patients without nephritis according to platelet indices.

\begin{tabular}{|c|c|c|c|c|c|}
\hline & $\begin{array}{l}\text { Control } \\
(\mathrm{n}=20)\end{array}$ & $\begin{array}{l}\text { Non nephritis } \\
(\mathrm{n}=54)\end{array}$ & $\begin{array}{c}\text { Nephritis } \\
(\mathrm{n}=26)\end{array}$ & Test of Sig. & $p$ \\
\hline$M P V(f l):$ & & & & & 0.947 \\
\hline Min. - Max. & $9.10-10.50$ & $8.0-13.60$ & $7.80-13.90$ & $\mathrm{~F}=0.054$ & \\
\hline Mean \pm SD & $9.94 \pm 0.30$ & $9.99 \pm 1.01$ & $10.03 \pm 1.34$ & & \\
\hline$P D W(\%):$ & & & & & 0.323 \\
\hline Min. - Max. & $10.70-18.80$ & $5.80-19.50$ & $8.90-19.70$ & $F=1145$ & \\
\hline Mean \pm SD. & $14.27 \pm 2.17$ & $13.20 \pm 2.72$ & $13.31 \pm 3.14$ & $1-1.14 J$ & 0.130 \\
\hline $\begin{array}{l}\text { PCT (\%): } \\
\quad \text { Min. - Max. } \\
\quad \text { Median }\end{array}$ & $\begin{array}{l}0.03-0.31 \\
0.26\end{array}$ & $\begin{array}{l}0.06-0.63 \\
0.24\end{array}$ & $\begin{array}{l}0.05-0.62 \\
0.20\end{array}$ & $\mathrm{H}=4.077$ & \\
\hline
\end{tabular}

F: ANOVA test. $\quad \mathrm{H}$ : Kruskal Wallis test. $\quad p: p$-value for comparing between the different groups.

Table (6): Correlation between SELEDAI score and platlet indices in cases group $(\mathrm{n}=80)$.

\begin{tabular}{lll}
\hline & \multicolumn{1}{c}{$r_{\mathrm{s}}$} & $P$ \\
\hline MPV (fl): & 0.083 & 0.465 \\
PDW (\%): & -0.045 & 0.694 \\
PCT (\%): & $-0.267 *$ & $0.017 *$ \\
\hline$r_{\mathrm{s}}$ : Spearman coefficient. & $*$ : Statistically significant at $p \leq 0.05$.
\end{tabular}

Table (7): Agreement (sensitivity, specificity) for PCT (\%) to predict severe flare patient.

\begin{tabular}{lccccc}
\hline & Cutoff & Sensitivity & Specificity & PPV & NPV \\
\hline PCT (\%) & $\leq 0.173$ & 61.11 & 79.03 & 45.8 & 87.5 \\
\hline
\end{tabular}




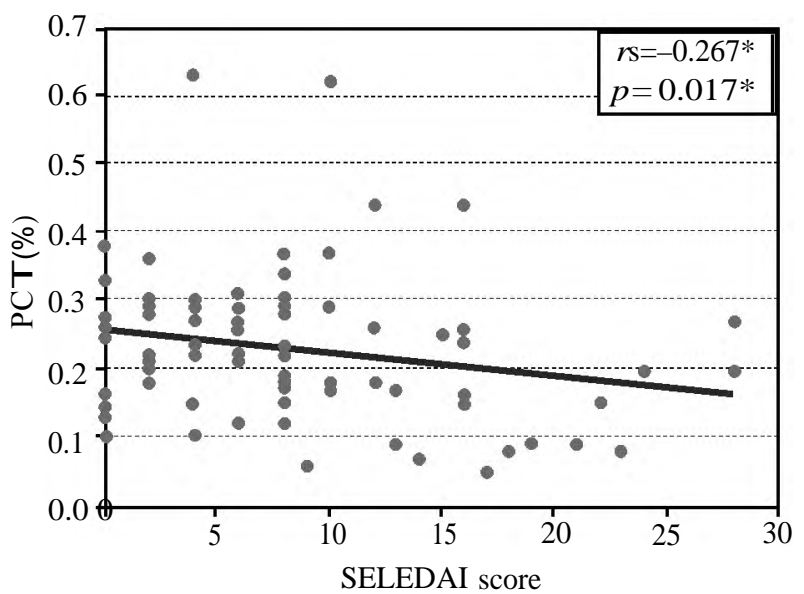

Fig. (1): Correlation between SELEDAI score and PCT (\%) in cases group $(\mathrm{n}=80)$.

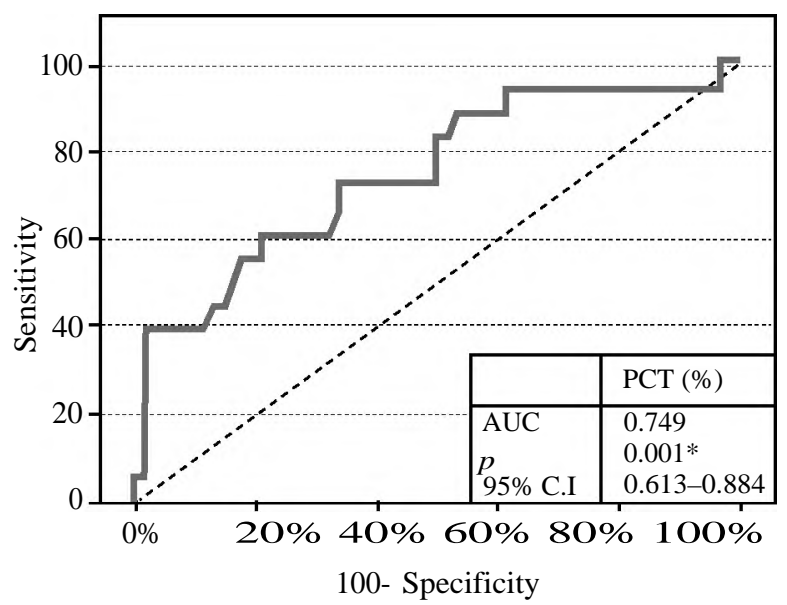

Fig. (2): ROC curve for PCT (\%) to predict severe flare patient

\section{Discussion}

Systemic lupus erythematosus is an autoimmune disease with frequent flares and remissions needs continuous monitoring of its activity. Some studies reported the association of platelet indices with some inflammatory and rheumatological diseases as rheumatoid arthritis, ankylosing spondylitis, behcets disease, systemic sclerosis and familial meditrenan fever (FMF) [9,12,17-22] but few studies tested this relation with SLE patients [23-25]. So we tried in this work to study the relation between SLE activity and platelet indices. We assessed MPV, PDW, PCT in 100 subjects; 20 healthy control and 80 SLE patients recruited from rheumatology unit in internal medicine department, Tanta University. The lupus patients divided into 20 patients without flare (SELEDAI <4), 17 patients mild flare (SELEDAI 4-<8), 25 patients moderate flare (SELEDAI $8-<12$ ) and 18 patients severe flare (SELEDAI $\geq 12$ ). Although we found that patients with moderate flare had lower mean values of hemoglobin and Heamatocrite than control group and the platelet count showed lower median values in severe flare patients than control group, MPV showed no statistical significance among studied groups and this in agreement with, El-Garf et al., 2016 who found that there was no significant difference in the MPV between juvenile SLE patients with low disease activity and those with active disease [26]. On the conterary some studies as Yavuz [27], Çankaya et al., [28], Sarkar [29] who reported higher MPV level in the active phase of SLE patients compared to their inactive disease period. Also Rupa [30], Safak [24], Khan et al., [31] reported that MPV was lower in active SLE patients than in inactive SLE patients.

This heterogenicity may be due to the difference in clinical characteristics, treatment strategies, sexual ratio and race, we could not explore associations between these factors and MPV level. The potential mechanism of decreasing MPV level in active SLE patients may attribute to the release of bioactive molecules of pro-inflammatory platelets and plasma platelet-derived micro-particle in the presence of inflammation. At a matter of fact, overproduction of pro-inflammatory cytokines can suppress bone marrow following the production of small-size platelet [32]. In regard to what cause the elevated MPV, active SLE patients tend to have vascular events and thrombocytopenia with a higher frequency resulting increasing MPV [33,34]

In our study also PDW showed no statistical significance among studied groups and this not in agreement with Chen et al., [35] who noticed higher PDW values in SLE patients than healthy controls and the positive relationship between PDW and disease activity but they reported that there are no other reports or studies on PDW in patients with SLE [35].

PCT showed lower values in lupus patients with severe flare than other groups with statistical significance $(p=0.007)$ between studied groups. There were no reported results regarding PCT in lupus but Metin et al., showed that the platelet-crit values seemed to be higher during active rheumatoid arthritis [36].

When we tried to find any relation or difference between lupus patients with and without nephritis in platelet indices our results showed no clinical significance between lupus patients with and without nephritis and this not in agreement with Yavuz et al., [27] who reported that MPV was superior to erythrocyte sedimentation rate, CRP and C3 to predict disease flares in juvenile SLE also Li L et 
al., [37] reported that MPV might be disease activity indicators for SLE nephritis. Lastly Çankayaetal determined that MPV increases during the active period of SLE patients with renal involvement [28]

We noticed also no correlation between MPV, PDW and SELEDAI but strong negative correlation between PCT and SELEDAI with cutoff value equals $\leqslant 0.173$, sensitivity $61.11 \%$, specificity $79.03 \%$, PPV $45.8 \%$ and NPV $87.5 \%$ in differentiating severe flare patients from other lupus patients and this in agreement with El-Garf etal who showed no correlation between MPV and SELEDAI [26], and not in agreement with Yavuz et al., who noticed that MPV was positively correlated with SLEDAI [27] and Delgado study where there was negative correlation between MPV and SELEDAI [23]. Chen et al., showed positive correlation between PDW and SELEDAI [35].

This study has some limitations as it is a single center study. In addition, the relative small sample size might affect its external validation. Another limitation that we did not report the patient medications and their effect on platelet indices. Also the selection of SLE patients who have different clinical complications, such as thrombocytopenia, or anti-phospholipid syndrome and vascular events may have different effect on these parameters.

So, we can conclude that mean platelet volume (MPV) and platelet distribution width (PDW) have no clinical significance in assessing lupus activity but Platelet-crit (PCT) can be used as a possible marker for SLE activity with cutoff value equals $\leq 0$. 173 , sensitivity $61.11 \%$, specificity $79.03 \%$, PPV $45.8 \%$ and NPV $87.5 \%$.

\section{Conflicts of interest: No conflict of interest.}

Funding: This research did not receive any specific grant from funding agencies in the public, commercial, or not-for-profit sectors.

\section{References}

1- DANCHENKO N., SATIA J. and ANTHONY M.: Epidemiology of systemic lupus erythematosus: A comparison of worldwide disease burden. Lupus, 15 (5): 308-18, 2006.

2- ISENBERG D. and RAMSEY-GOLDMAN R.: Assessing patients with lupus: Towards a drug responder index. Rheumatology, 38 (11): 1045-9, 1999.

3- SYMMONS D., COPPOCK J., BACON P., BRESNIHAN B., ISENBERG D., MADDISON P., et al.: Development and assessment of a computerized index of clinical disease activity in systemic lupus erythematosus. QJM: An International Journal of Medicine, 69 (2): 927-37, 1988.

4- GRIFFITHS B., MOSCA M. and GORDON C.: Assessment of patients with systemic lupus erythematosus and the use of lupus disease activity indices. Best practice \& research Clinical rheumatology. 19 (5): 685-708, 2005.

5- ROMERO-DIAZ J., ISENBERG D. and RAMSEYGOLDMAN R.: Measures of adult systemic lupus erythematosus: Updated Version of British Isles Lupus Assessment Group (BILAG 2004), European Consensus Lupus Activity Measurements (ECLAM), Systemic Lupus Activity Measure, Revised (SLAM-R), Systemic Lupus Activity Questionnaire for Population Studies (SLAQ), Systemic Lupus Erythematosus Disease Activity Index 2000 (SLEDAI-2K), and Systemic Lupus International Collaborating Clinics/American College of Rheumatology Damage Index (SDI). Arthritis Care \& Research, 63 (S 11): S37-S46, 2011.

6- LIANG M.H., SOCHER S.A., LARSON M.G. and SCHUR P.H.: Reliability and validity of six systems for the clinical assessment of disease activity in systemic lupus erythematosus. Arthritis \& Rheumatism: Official Journal of the American College of Rheumatology, 32 (9): 1107-18, 1989.

7- THREATTE G.A.: Usefulness of the mean platelet volume. Clinics in laboratory medicine. 13 (4): 937-50, 1993.

8- YÜKSEL O., HELVACı K., BAŞAR Ö., KÖKLÜ S., CANER S., HELVAC1 N., et al.: An overlooked indicator of disease activity in ulcerative colitis: Mean platelet volume. Platelets. 20 (4): 277-81, 2009.

9- KISACIK B., TUFAN A., KALYONCU U., KARADAG O., AKDOGAN A., OZTURK M.A., et al.: Mean platelet volume (MPV) as an inflammatory marker in ankylosing spondylitis and rheumatoid arthritis. Joint Bone Spine. 75 (3): 291-4, 2008.

10- ENDLER G., KLIMESCH A., SUNDER-PLASSMANN H., SCHILLINGER M., EXNER M., MANNHALTER C., et al.: Mean platelet volume is an independent risk factor for myocardial infarction but not for coronary artery disease. British Journal of Haematology. 117 (2): 399404, 2002.

11- BATH P., ALGERT C., CHAPMAN N. and NEAL B.: Association of mean platelet volume with risk of stroke among 3134 individuals with history of cerebrovascular disease. Stroke. 35 (3): 622-6, 2004.

12- IBRAHIM S.E., MORAD C.S., FAROUK N. and LOUIS A.: Platelet indices as markers of inflammation in systemic sclerosis patients: Relation to vascular endothelial growth factor and flow mediated dilatation. The Egyptian Rheumatologist. 40 (4): 239-42, 2018.

13-OSSELAER J-C., JAMART J. and SCHEIFF J-M.: Platelet distribution width for differential diagnosis of thrombocytosis. Clinical Chemistry, 43 (6): 1072-6, 1997.

14- CHANDRASHEKAR V.: Plateletcrit as a screening tool for detection of platelet quantitative disorders. Journal of Hematology. 2 (1): 22-6, 2013.

15- PETRI M., ORBAI A.M., ALARCÓN G.S., GORDON C., MERRILL J.T., FORTIN P.R., et al.: Derivation and validation of the Systemic Lupus International Collaborating Clinics classification criteria for systemic lupus erythematosus. Arthritis \& Rheumatism, 64 (8): 2677 86, 2012.

16- TOUMA Z., GLADMAN D.D., IBAÑEZ D. and UROWITZ M.B.: Development and initial validation of the systemic lupus erythematosus disease activity index 2000 
responder index 50. The Journal of rheumatology. 38 (2): 275-84, 2011

17- YURI GASPARYAN A., AYVAZYAN L., P MIKHAILIDIS D. and D. KITAS G.: Mean platelet volume: A link between thrombosis and inflammation? Current pharmaceutical design. 17 (1): 47-58, 2011.

18- YAZICI S., YAZICI M., ERER B., ERER B., CALIK Y., OZHAN H, et al.: The platelet indices in patients with rheumatoid arthritis: Mean platelet volume reflects disease activity. Platelets, 21 (2): 122-5, 2010.

19- YAZICI S., YAZICI M., ERER B., ERER B., ÇALIK Y., BULUR S., et al.: The platelet functions in patients with ankylosing spondylitis: Anti-TNF-a therapy decreases the mean platelet volume and platelet mass. Platelets. 21 (2): 126-31, 2010.

20- SOYDINC S., TURKBEYLER I.H., PEHLIVAN Y., SOYLU G., GOKTEPE M.F., BILICI M., et al.: Mean platelet volume seems to be a valuable marker in patients with systemic sclerosis. Inflammation, 37 (1): 100-6, 2014.

21- ULUCA Ü., DEMIR F., ECE A., ŞEN V., GÜNEŞ A., AKTAR F., et al.: Assessment of epicardial adipose tissue thickness and the mean platelet volume in children with familial Mediterranean fever. Italian Journal of Pediatrics. 41 (1): 15, 2015.

22- ACIKGOZ N., KARINCAOGLU Y., ERMIS N., YAGMUR J., ATAS H., KURTOGLU E., et al.: Increased mean platelet volume in Behçet's disease with thrombotic tendency. The Tohoku journal of experimental medicine. 221 (2): 119-23, 2010.

23- DELGADO-GARCÍA G., GALARZA-DELGADO D.Á., COLUNGA-PEDRAZA I., BORJAS-ALMAGUER O.D., MANDUJANO-CRUZ I., BENAVIDES-SALGADO D., et al.: Mean platelet volume is decreased in adults with active lupus disease. Revista brasileira de reumatologia. 56 (6): 504-8, 2016.

24- SAFAK S., USLU A.U., SERDAL K., TURKER T. SONAR S. and LUTFI A.: Association between mean platelet volume levels and inflammation in SLE patients presented with arthritis. African Health Sciences, 14 (4): 919-24, 2014

25- SAHIN A., YETISSGIN A., SAHIN M., DURMAZ Y. and CENGIZ A.: Can mean platelet volume be a surrogate marker of inflammation in rheumatic diseases? West Indian Medical Journal. 65 (1), 2016.

26- EL-GARF K., MARZOUK H., FARAG Y., RASHEED L. and EL-GARF A.: Mean platelet volume is a marker of inflammation but not a marker of disease activity in children with juvenile SLE. The Egyptian Rheumatologist. 38 (1): 35-9, 2016
27- YAVUZ S. and ECE A.: Mean platelet volume as an indicator of disease activity in juvenile SLE. Clinical Rheumatology. 33 (5): 637-41, 2014.

28- CANKAYA E., BILEN Y., BILEN N., UYAN1K A., KELEŞ M.: Sp 187 mean platelet volume significantly decrease at remission period of sle patients with renal involvement. Nephrology Dialysis Transplantation, 30 (suppl-3): iii439-iii, 2015.

29- SARKAR R., BHATTACHARYA K. and BANERJEE M.: Mean platelet volume as an indicator of disease activity in systemic lupus erythematosus. The Journal of the Association of Physicians of India, 64 (1): 68, 2016.

30- RUPA-MATYSEK J., GIL L., WOJTASIN'SKA E., CIEPL' UCH K., LEWANDOWSKA M. and KOMARNICKI M. The relationship between mean platelet volume and thrombosis recurrence in patients diagnosed with antiphospholipid syndrome. Rheumatology International, 34 (11): 1599-605, 2014.

31- KHAN A., HAIDER I., AYUB M. and KHAN S.: Mean Platelet Volume (MPV) as an indicator of disease activity and severity in lupus. F1000Research. 6, 2017.

32- GASPARYAN A.Y., SANDOO A., STAVROPOULOS KALINOGLOU A., KITAS G.D.: Mean platelet volume in patients with rheumatoid arthritis: The effect of antiTNF-alpha therapy. Rheumatology International, 30 (8): 1125-9, 2010.

33- SCHERLINGER M., SISIRAK V., RICHEZ C., LAZARO E., DUFFAU P. and BLANCO P.: New insights on platelets and platelet-derived microparticles in systemic lupus erythematosus. Current rheumatology reports. 19 (8): 48, 2017.

34- BAI M., XING L., FENG J., CUI C., HUANG L. and LIANG G.: Mean Platelet Volume Could Reflect Disease Activity of Adult Patients With Systemic Lupus Erythematosus. Clinical laboratory. 62 (7): 1317-22, 2016.

35- CHEN S-Y., DU J., LU X-N. and XU J-H.: Platelet distribution width as a novel indicator of disease activity in systemic lupus erythematosus. Journal of Research in Medical Sciences: The Official Journal of Isfahan University of Medical Sciences. 23, 2018.

36- IŞ1K M., ŞAHIN H. and HÜSEYIN E.: New platelet indices as inflammatory parameters for patients with rheumatoid arthritis. European journal of rheumatology. 1 (4): 144, 2014.

37- LI L., XIA Y., CHEN C., CHENG P. and PENG C.: Neutrophil-lymphocyte ratio in systemic lupus erythematosus disease: A retrospective study. International Journal of Clinical and Experimental Medicine. 8 (7): 11026 , 2015. 


\section{تغيرات مؤثرات الصفائح الدموية فى مرضى الذئبة الحمراء وأرتباطها بنشاط المرضح في مرضي}

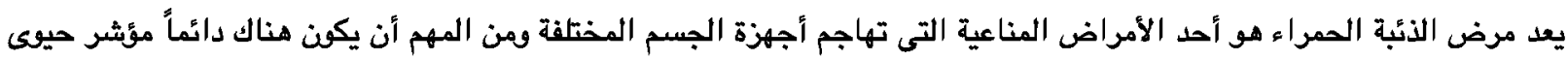

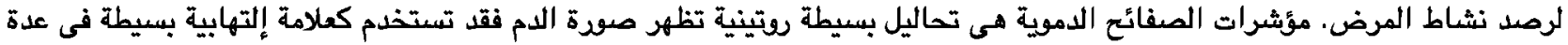
أمراض مثل الأمراض الروماتيزمية كمرض الرومات الرواتويد المفصلى وتقرحات القولون.

الهدف من الدراسة: التعرف على مؤشرات الصفائح الدموية فى مرضى النئبة الحمراءومدى أرتباطها بنشاط المرض.

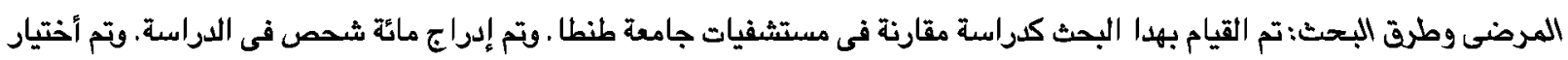

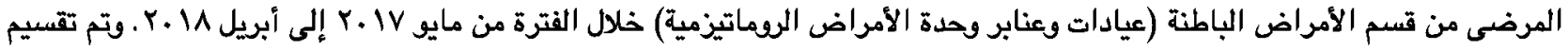

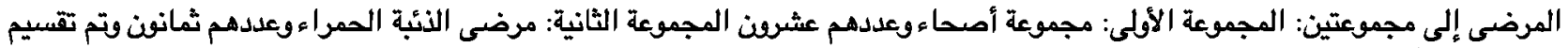

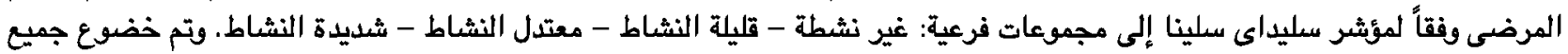

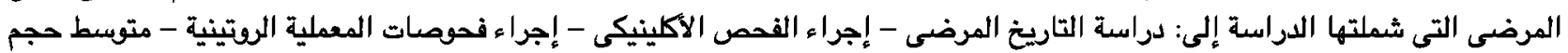

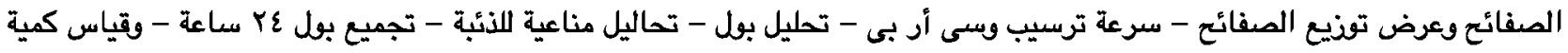

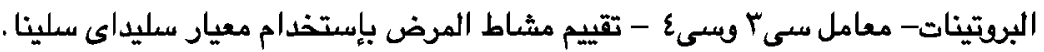

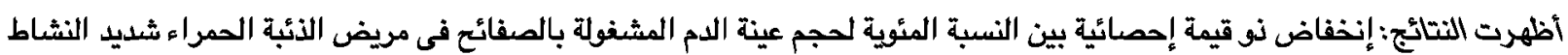

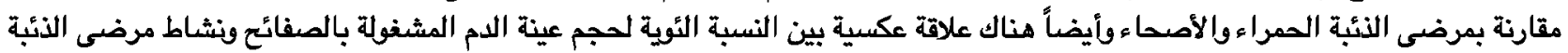
الحمراء المقاس بمعيار السليداي سلينا.

الأستتاج والخلاصة: من تقييم نتائج هذه الرسالة ومقارنتها بنتائج الأبحاث الأخرى فى نفس المجال يمكن التوصل إلى إستخدام النسبة

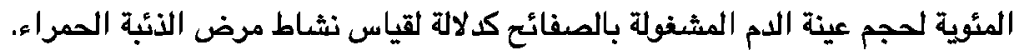

